\title{
From new clones to flowers - innovative business models in the Hungarian wine economy
}

\author{
Balázs Kismarjai \\ Eötvös Loránd University, Department of Social and Economic Geography, 1117 Budapest, Pázmány Péter sétány 1/C, Hungary
}

\begin{abstract}
Due to the ovestocked Hungarian wine sector wineries often need to find entirely new ways that enable them to increase their market share. These opportunities are determined by the current market potentials, the geographic location and of course the wine district itself. In this study I examined some examples of outbreak opportunities for producers in this difficult economic situation. Young winemakers from different Hungarian wine districts unite to open wine bars - these are now present in several towns all over the country. Other winemakers have been experimenting with new clones in less recognized wine districts. A small winery from a historic wine district recommends its wines with flowers in a new shop.
\end{abstract}

\section{Introduction}

Based on experiences from the past years it is reasonable to say that the Hungarian wine market has been going through significant and dynamic changes. Fortunately for the wine consumers there is a new generation the members of which are looking for quality wines, so it forces the winemakers to dismiss low-quality table wines ordinary in socialist era. Beside the "great veterans" expropriating the wine market after the end of the communist regime new generations have grown up, small family wineries have appeared as well as modern wineries with up-todate technologies procreated by investors. Due to the EU subsidies the technological gap has narrowed, so smaller producers are capable of building up modern wineries.

Meanwhile, due to the increased wine-making capacity the Hungarian wine market has been greatly overstocked. One can tend to think that the competition on wine market takes place only among wine makers for the sake of consumers. However the competition on the wine market is twofold. On the one hand it is a real competition among wineries to introduce a product to the market, catch and keep the consumers with the wine label and brand. The necessary marketing absorbs significant amount of money not to mention adjunct costs such as being present in bigger supermarkets. On the other hand, there is a sharpening competition among vine varieties and types of wines as well, for the producers have to find a sensitive equilibrium between red, white and rosé wines, as well as between the worldwide known grape varieties and the so called hungaricums ${ }^{1}$. Furthermore, viticulture and wine-making is affected by climate change. Thus, the winemakers have to take into consideration the local climate and other

\footnotetext{
${ }^{1}$ Hungaricum is an animal, a plant or a product made from it, which is related to the Hungarian production culture, habits or traditions. The Hungaricums are accepted by the Hungarians as specific and well-known things and the Hungaricums are connected with the Hungarian roots by the foreigners too [1].
}

biophysical factors when planting grapes or selecting the appropiate technology [5].

Of course, these two competition factors are correlated, but they have different impacts. The first type of competition primarily affects the producers in the form of increasing prestige and income, while the main beneficiaries of the second competition type are the consumers who can taste more and more new wines.

The newcomers on wine market have to face a serious challenge, namely reaching a market share that ensures their pay-off and selling their products. Because of this they need proper marketing to create a special, unique product or to formulate a special product tie to base on it. To reach these purposes they need to perform market surveys as well. Unfortunately, these processes are not well-rooted in Hungarian wine-business traditions, as the assigned amount of money is missing from the production process itself. Several promising new wineries went under because they did not measure properly their possibilities, like the current market gaps.

Despite the initial difficulties wine producing enterprises can be remunerative in the long run. The ones surviving this period are stable, their survival ratio is the highest among agricultural enterprises [13].

\section{Innovation examples}

This publication shows three different ways of reaching bigger market shares by winery managers. These innovations point ahead, they prove the long-term thinking of the investors/owners.

\subsection{Licence Koch Winery - new clones, new wines}

Csaba Koch has been cultivating his domain in the southern part of the Hungarian plain, in the Hajós-Baja wine region since 1991. In this region one can find 130 hectares of vineyards out of the total 140 hectares owned by Koch (the remaining ten hectares are in the 
Villány wine region). The soil of the Hajós-Baja wine region is mainly sand and loess and this region is charactirized by the highest sunny hours ratio per year in Hungary (2070 sunny hours/year). Therefore the grown grape varieties are relevant to these facts: Blaufrankisch, Kadarka and the cabernet-type grape varieties dominate among the red grapes and the aromatic, redolent white grape varieties such as Cserszegi fúszeres (füszeres means 'spicy'), Irsai Oliver, Muscat Ottonel are the most popular [2].

The Koch Winery producing about 900.000 bottles of wine yearly and employing 70 employees belongs to bigger Hungarian wineries. Besides the Hungarian market the winery exports its products to several European countries (e.g. France, Germany) and overseas as well (e.g. Brazil, South-Korea). The main traditional grape varieties of the winery are the Cserszegi fúszeres, Cabernet sauvignon, Muscat Ottonel, Blaufrankisch and Chardonnay. They produce 25-26 types of wines that vary from table wines to premium selections.

Alongside with others these facts have led the owners to start experimenting with new varieties. According to Koch that is to say, the wines from the lower part of the product range should not be made from the same grape varieties as the premium wines. On the basis of these ideas the winery has been experimenting with new clones for 12-13 years. Naturally, this kind of experiment requires a scientific background [5]. Cooperation among Koch Winery, Grape Breeding Gene Conservation Department of Vine, Wine Institute of University of Pécs and its leader, Dr Pál Kozma is pre-eminent. By now half a dozen of clones have been planted and are being investigated meanwhile.

The experiment is based on the recognition that due to its asexual propagation the grapevine is unable to accomodate properly. As a result the genetic codes of the old Vinifera varieties are not changing, so the grapes are incapable against pathogens. With weak resistance they have to be sprayed with powerfull and highly toxic chemicals, which makes ecological and organic production of wines impossible. The purpose is to breed clones that are possibly fully resistant to downy mildew, powdery mildew or grey rot by the process of crossbreeding and applying the most up-to-date technology of gene manipulation. Koch believes it is clear that gene manipulation and breeding resistant varieties must be the foundation of tomorrow's viticulture.

Anyway, the Koch winery is devoted to ecological grape production not using insecticides and trying to minimize applying fungicides. The soil between the grape lines is covered by natural vegetation or sward and instead of applying chemicals they leave killing the pests to nature. Also, they place artificial bird nests to the vineyards.

While breeding new clones they have been paying attention to the different soil types as well. The black soil of the region has a very high humus content accompanied with good lime and other nutrients. The water supply of the above mentioned area between the Danube and the Tisza will be one of the key factors in the next decades which also deserves special attention.

Two of the applied clones in wine production have been already used on bigger territories. The Bácska clone is grown on 15 hectares, the Pannonia clone on 12 hectares. The Bácska clone matures into a kind of mid-quality

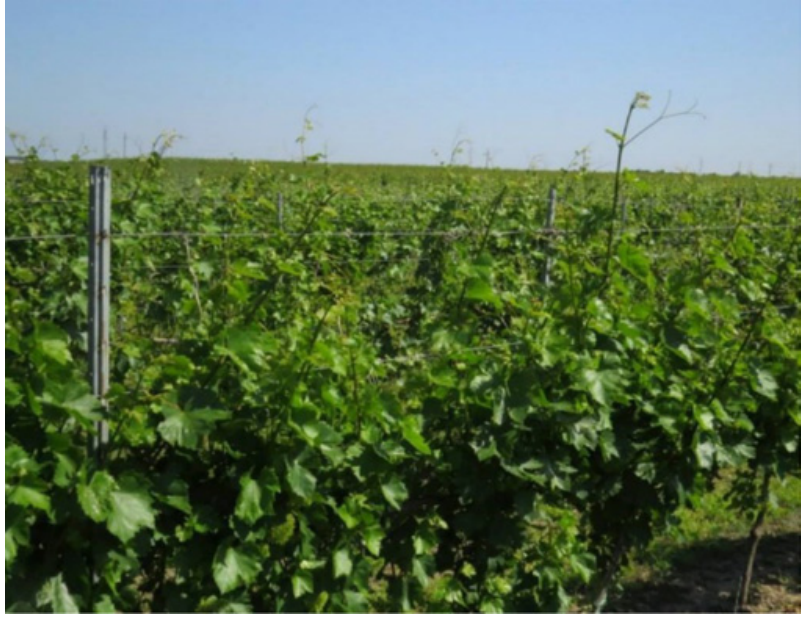

Picture 1. Vineyard at Borota. Source: www.facebook.com/ kochboraszat.

grape, with similar taste and aromatic compounds as the Müller-Thurgau and with high load at the same time, so it can be suitable to make high volume base wine. The Pannónia clone is a definitely good quality variety with outstanding resistance. Half of its genetic stock is inherited from Reisling, so the wine made from it reminds the Reisling type. Even though the yield of vine bases is relatively low (100-110 q/ha), the quality is excellent.

The wines made from the new clones have still been under investigation. The purpose is that the wines come onto the market as organic, however three years have to pass before the qualification procedure is carried out. According to Koch's plans, the vintage of 2018 will be introduced to the market as well distinguished brands from the traditional wines of the winery using differend marketing strategy. The rest is up to the customers.

\subsection{Junibor - Association of Young Winemakers/DiVino - "it is good to be a young winemaker nowadays!"}

The Junibor association was founded in 2008 based on ideas of mainly young, second-generation winemakers. The original idea was to create an association which helps the professional development of its members. Study tours, forums and professional cooperation give the possibility to increase professional experience of the members. Today the association has 34 members from 13 out of the 22 Hungarian wine regions. One of their main purpose is to recruit young wine makers from all the wine regions. At the same time admission is limited. The potential member has to be younger than 35 years old and one can only be a member until the age of 40 . Furthermore, in spite of the fact that the members of this wine maker generation know each other well, the prerequisite of admission is a procedure including an interview, introduction, tasting and voting.

Naturally, one of the tasks of the association is to propagate the culture of responsible, self-conscious wine consumption. This intention got a great support from an outsider idea, namely to distribute the wines made by the members of the association collectively. The owners came up with a determined conception of not allowing wines made by non-members to be put on their wine list. 
The wine bar rooted in this idea was given the name of DiVino. The wine bar which was opened in 2011 in a frequented place next to the Basilica in Budapest, has become a must-see place for wine consumers. The great amount of young dedicated wine makers cooperating with each other is an inimitable possibility and a spiritual capital to start with. Making use of this fact the bar owners have managed to give rise to a franchise with several members. The first franchise-member bar was opened in Budapest too, taking advantage of the popularity of the city among youngsters from the West. The DiVino Gozsdu was opened in the party district where it reached significant share and outstanding guest traffic among other bars and restaurants offering similar high standard services.

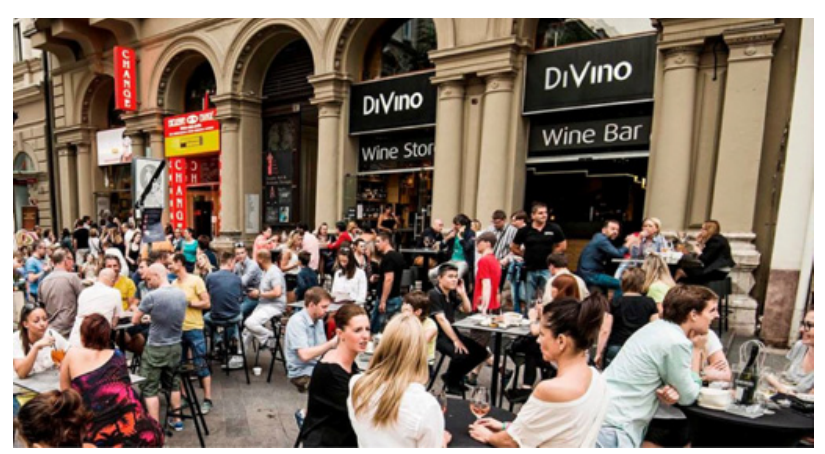

Picture 2. An ordinary summer day on DiVino's terrace. Source: www.facebook.com/DiVinowinebar.

Beacuse of the Hungarian demographic and ecomomic trends the rural enterprises like DiVino have to face serious risks. In spite of this it seems that DiVino Debrecen (2014) and DiVino Győr (2014) are likely to become successful. Naturally, the size and the volume of the guests do not reach the dimensions of the Budapest DiVino, but the well-selected locations (main squares) can guarantee the sufficient guest traffic. The purpose of the owners is the further extension of the franchise system mainly in Hungary. According to the plans three other DiVino bars are going to be opened not later than in 2017. Kecskemét, Székesfehérvár and the tourist-capital of lake Balaton Balatonfüred, will get premium wines. The international expansion represents long term pursuits, primarily in the Carpathian Basin. Though not in a DiVino bar, wines made by members of the Junibor Association can be purchased in Cluj-Napoca, Romania (Kolozsvár). Further extension needs serious and comprehensive tourism and marketing analyses. Based on them the potential cities could be the ones that have outstanding tourist attractiveness (e.g. Krakow in Poland).

As the necessary part of the extension, marketing is managed by a special professional company. In one respect it helps operate the wine bars with ads, secondly it helps Junibor members to synchronize their advertising activities.

The exceptional wonderful place next to the Basilica allowed the Budapest DiVino being the "mother-bar" of the franchise system to organize the fifth Junibor Wine Festival in Szent István Square in 2016.

The members of the Junibor Association sell their wines here as well as at other traditional wine festivals.

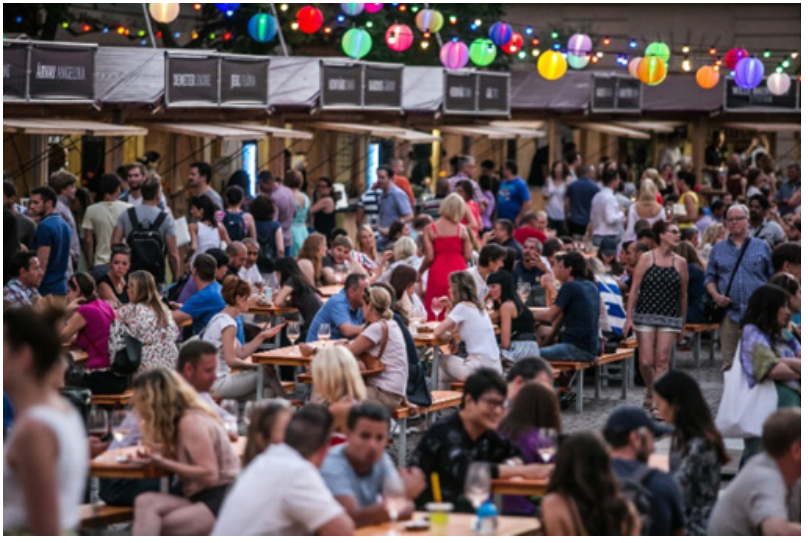

Picture 3. V. Junibor Wine Festival. Source: www.facebook. com/DiVinowinebar.

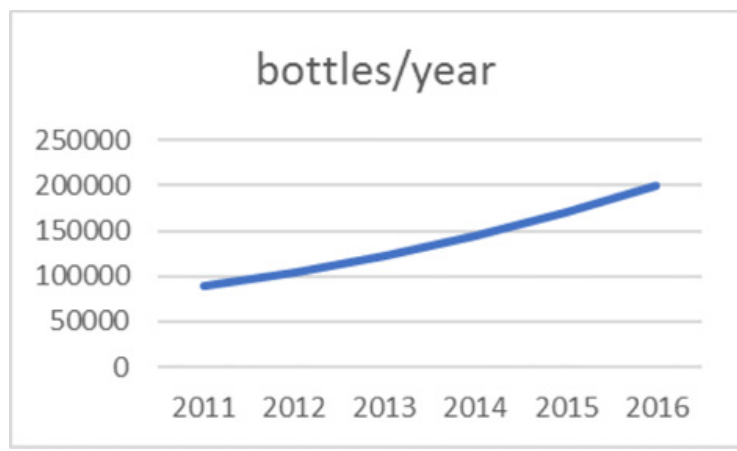

Source: DiVino

Figure 1. Number of sold bottles in the bars of DiVino franchise system. Source: DiVino.

The festival is really successful and the guarenteed quality of wines attracts thousands of visitors to the festival each day of the event (totally eight thousand guests in 2016).

With its quality drinks and foods the DiVino wine bar serves the expert and interested guests at a high level. Today it owns the "Michelin" and "Bib Gourmand" recommendations. These titles naturally increase the traffic rooted in popularity. During the last six years after opening the bar it has been raising its traffic continuously. Last year resulted in 200.000 sold bottles.

\subsection{Wines\&Roses - wines with flowers}

Csaba Miklós, the young wine maker from the wine region of Mór has graduated as a horticulturist, so besides the wines flowers are close to him as well. This background gave him an idea to link these two products and open a shop in Budapest with the name of Wines\&Roses.

The Mór wine district, which is an old traditional wine producing settlement, is situated to the west of Budapest, about ninety kilometers far from the capital. This wine district covering all in all 724 ha (2011) is one of the smallest out of the total 22 Hungarian wine districts. It primarily produces white wines the typical varieties of which include the local-specific Ezerjó, Sauvignon blanc, Reisling and Pinot blanc. Among the very few red wines Blaufrankisch should be mentioned $[2,4,8]$.

Miklós's winery ("miiklóscsabi's winery") can be found here and he cultivates his vineyards on 3,5 ha. Being a family winery he isn't planning to buy more vineyards. 


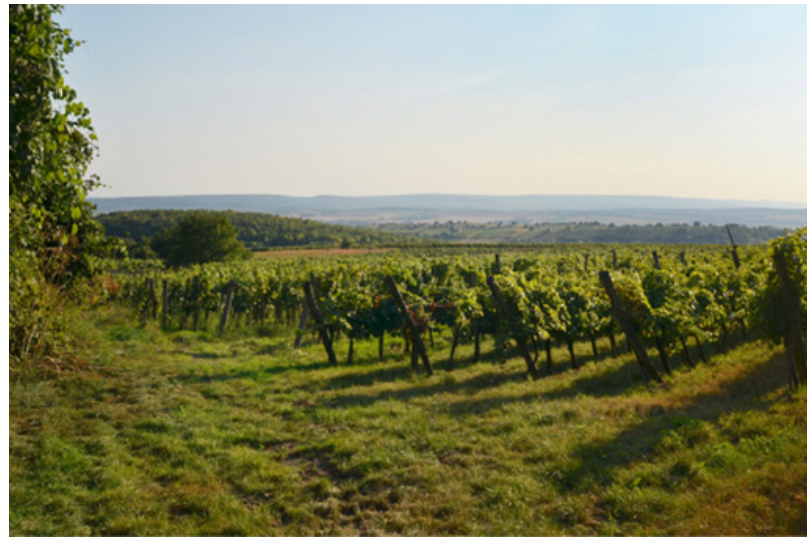

Picture 4. Mór, Csóka-vineyard. Source: www.mikloscsabi . com.

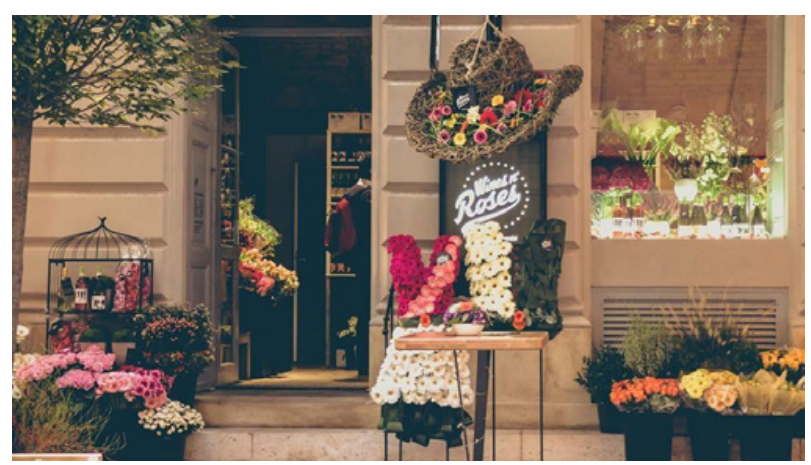

Picture 5. Wines\&Roses Shop. Source: www.facebook.com/ wnrbudapest.

They produce about 15.000 bottles of wines yearly and due to the well structured marketing and popularity they can sell most of them. Yet, to increase the popularity of the winery and bridge the seasonal trade Miklós has been looking for new ways. One of these can be matching flowers and wines.

Miklós sells only his own wines in his shop, so he obtains the flowers according to the principles of fair-trade mostly from Kenyan producers (e.g. Credible Blooms, PJ Dave Group, Waridi Farm), in smaller extent from Dutch producers (e.g. Dutch Flower Group, Zandbergen Group). This ensures that seasonal flowers are constantly arriving at the shop through the shortest way. Besides the vasedurability the all-year-round prices are guaranteed in his shop.

The shop has not had a long history yet. The owner keeping to his conseption has been awaiting for customers for a year now. The flowers are sold not only in a traditional manner (packed in cellophane) as imprinted in the last decades, but in cut-bouquets or even in trusses. The purpose is to make buyers feel like decorating and placing flowers in their houses creatively. At the same time Miklós recommends his wines, as his motto "passionate weekdays" matches the flavours of wines and flowers.

\section{Summary}

As the examples detailed above show, competition forces the wine makers to do their best. In order to achieve the operation costs and reach some profit, the wine makers are continuously coming up with new ideas. One can hope that these ideas will work in the long run and serve as examples of good practices for other wine makers considering similar innovations. Hungarian wine makers can only be successful as opposed to the New World's wine dumping with innovative and striking ideas and producing quality, unique and specific grapes and wines [5]. The relation between scientific and economic domains has an increasingly important role as well. Cooperation, technological transfer from science to production and the direct involvement of researchers into the economical processes could provide kind of an advantage that should not be lost [5].

\section{References}

[1] A. Andrásfalvy, A kertészeti hungarikumok sajátos minősége, MTA Társ. Kut. 25 (2003)

[2] G.B. Bányai, D. Ercsey, G. Mészáros, I. Tompa, Nagy Magyar boratlasz (2012)

[3] E.P. Botos, K.S. Moulton, Wine prod. and distr., OIV Congr. (2007)

[4] Sz. Frey, L. Száraz, Az ezerjó hazája (2010)

[5] E. Giuliani, A. Morrison, R. Rabellotti ed, Innovation and technological catch-up (2011)

[6] I-né Hajdú ed, Borpiac (2005)

[7] G. Harsányi, A hazai borágazat versenyképessége (2007)

[8] Á. Kiss, Az ezerjó hazájában (1990)

[9] J. Lehota, Market orientation and comp. OIV Congr. (2007)

[10] E. Nagy-Kovács, A szőlô- és bortermékpálya jövedelmezősége (2011)

[11] I. Szúcs, M. Farkasné Fekete ed, Hatékonyság a mezőgazdaságban (2008)

[12] G. Totth, Gazd. 2, 140 (2016)

[13] G. Valkó, Á. Kincses, Gazd. 1, 3 (2014) 